\title{
Reproductive-somatic relationships in Loligo gahi (Cephalopoda: Loliginidae) from the Falkland Islands
}

\author{
ANGEL GUERRA and BERNARDINO G. CASTRO \\ Instituto de Investigaciones Marinas (CSIC),Eduardo Cabello 6, 36208 Vigo, Spain
}

\begin{abstract}
Samples of Loligo gahi from the Falkland Islands Interim Conservation and Management Zone collected in March 1987 were analysed to determine the relationships between mass of reproductive and somatic organs during maturation. There was a progressive increase in mass of the reproductive organs with growth in males, while in females these organs did not show a conspicuous increase in mass until a body mass of $c .40 \mathrm{~g}$ was reached. No change was found in the mass of the digestive gland in relation to body mass or in the water content of male and female somatic tissues during maturation. Growth of reproductive organs in L. gahi seems to be supported by diet and not at the expense of somatic tissue.
\end{abstract}

Received 5 July 1993, accepted 14 October 1993

Key words: Loligo gahi, maturation, growth, Falkland Islands

\section{Introduction}

Cephalopods are very active organisms with high metabolic costs supported by high rates of food ingestion ( $O^{\prime}$ Dor \& Wells 1987). The food ingested has to provide enough energy and nutrients for their routine and active metabolism, rapid growth and reproduction. Feeding rate, growth and reproduction are strongly related in cephalopods. In female Octopus vulgaris gonaddevelopment constricts the gut preventing feeding(O'Dor \& Wells 1978). Moreover, the posterior salivary glands degenerate as does the digestive gland; even if an Octopus did take a crab, it would be unable to digest it (Tait 1986, Mangold et al. 1993). Experimentally starved Illexillecebrosus accelerate their sexual maturation (Rowe \& Mangold 1975). Increasing energy demand for gonad development can reduce or even halt somatic growth. Also, if food ingestion is limited, somatic tissues may be used for gonad production, sometimes leading to individuals being emaciated at spawning (Hamabe 1969, O'Dor $\&$ Wells 1987). The semelparous life cycle of many cephalopods favours this dramatic shift of nutrients and energy from growth to reproduction. Nevertheless, some species have been reported not to break down somatic tissues for gonad production but to derive all the necessary energy from food (Mangold et al. 1993).

Loligo gahi d'Orbigny 1835 is a neritic loliginid squid distributed over the continental shelf and the slope of the Eastern Pacific Ocean from southern Peru to southern Chile, and in the South Atlantic from the Gulf of San Matías to Tierra del Fuego (Roper et al. 1984,Brakoniecki 1986). It is caught commercially using both pelagic and bottom trawls during two fishing seasons, February-June and August-September, usually within the depth range 140-200 m (Hatfield et al. 1990). Catches inside the Falkland Islands Interim Conservation and Management Zone (FICZ) were $82500 \mathrm{t}$ in 1987 (Anon. 1989). Hatfield et al. (1991) report recruitment of two or three broods into the fishery peryear. The lifespan of the species approximates one year (Patterson 1988, Hatfield 1991), although Arancibia \& Robotham(1984) have estimated a lifespan of two or three years in southern Chile. There is evidence that $L$. gahi spawns and dies in shallow water and the next generation migrates offshore where it grows and matures (Hatfield et al. 1990). Females attain a larger size than males, but males mature earlier than females and attain full sexual maturity at a younger age and at a smaller size (Hatfield et al. 1990).

Few data are available on maturation of $L$. gahi males and females, and little is known about the expenditure of nutrients and energy for the development of reproductive organs. In both sexes of the ommastrephid squid Illex argentinus from the Patagonian shelf, production seems to shift from growth to reproductive organs during the course of maturation. The development of reproductive organs is supported by the squid's food and not at the expense of somatic tissue (Hatfield et al. 1992, Rodhouse \& Hatfield 1992).

In this paperwe examine whether somatic tissue is remobilized for growth of reproductive organs during maturation in male and female L. gahi.

\section{Materials and methods}

Loligo gahi were taken from a Spanish trawler fishing within the FICZ in March 1987. A total of 130 males and 189 females were examined. Size ranged from $70-170 \mathrm{~mm}$ mantle length, representing $95 \%$ of the size range present in the fishery during that fishing season (Hatfield et al. 1991). They were defrosted at room temperature. After dissection sex was determined and assigned a maturity stage I-IV according to the Ngoile's (1987) maturity scales forLoligo forbesi, butconsidering stages IV and $V$ as stage IV. Thus, stage I is immature, II and III maturing and IV fully mature. The composition by maturity stages was: 141 immature, 46 maturing and two mature females; five immature, 
Table I. Summary of mean \pm SD values of body components and indices for Loligo gahi males and females and maturity stages. $n=$ number of specimens; BM = total body mass; VI - Visceral Index (see text for definition); EBWC = percentage of water content in eviscerated body mass; DGI = Digestive Gland Index (see text for definition); DGWC = percentage of water content in digestive gland; RSI = Reproductive Somatic Index (see text for definition).

\begin{tabular}{|c|c|c|c|c|c|c|c|}
\hline Maturity stages & $n$ & BM & $\mathrm{VI}$ & EBWC & DGI & DGWC & RSI \\
\hline \multicolumn{8}{|l|}{ Males } \\
\hline I & 5 & $25.7 \pm 9.0$ & $4.8 \pm 1.1$ & $80.4 \pm 1.2$ & 3.320 .8 & $77.1 \pm 0.9$ & $0.9 \pm 0.5$ \\
\hline II & 66 & 32.727 .0 & 6.421 .1 & 80.821 .2 & 3.120 .7 & 79.022 .5 & 2.020 .5 \\
\hline III & 44 & $44.1 \pm 13.9$ & 6.621 .7 & 80.521 .2 & 3.020 .7 & $77.7 \pm 2.8$ & $2.6 \pm 1.1$ \\
\hline IV & 15 & 54.0216 .5 & $9.2 \pm 2.3$ & 79.220 .9 & $2.7 \mathrm{k} 0.6$ & 77.721 .8 & 5.421 .9 \\
\hline \multicolumn{8}{|l|}{ Females } \\
\hline I & 141 & 30.427 .0 & $4.8 \pm 1.4$ & $81.3 \mathrm{k} 1.1$ & $3.2 \pm 0.9$ & 79.022 .7 & 0.320 .3 \\
\hline II & 38 & $35.5 \mathrm{k} 7.6$ & 5.721 .6 & 80.921 .2 & $3.3 \pm 0.8$ & 79.221 .9 & $0.9 \pm 0.8$ \\
\hline III & 8 & $50.5 \pm 9.9$ & $7.8 \pm 2.5$ & 81.221 .5 & $3.2 \pm 1.0$ & 79.023 .0 & 2.720 .9 \\
\hline IV & 2 & $42.8 \pm 0.8$ & $7.6 \pm 0.1$ & 79.220 .1 & $3.7 \pm 0.0$ & $75.5 \pm 0.9$ & $3.2 \pm 0.2$ \\
\hline
\end{tabular}

114 maturing and 15 mature males. Thefollowing measurements were made: mantle length (ML); wet body mass (BM); wet digestive gland mass (DGM); reproductive organ mass (RM), comprising the testis, sperm duct, spermatophoric organ, spermatophoric duct, spermatophoric sac and penis in males, and ovary, proximal and distal ducts, accessory and nidamental glands in females; eviscerated wet mass (EBM), comprising mantleand head massincluding arms and tentacles. Eviscerated dry mass and digestive gland dry mass were also recorded after drying both eviscerate specimens and digestive glands at $105^{\circ} \mathrm{C}$ for $24 \mathrm{~h}$. Visceral mass (VM) was estimatedby subtracting total eviscerate wet mass from body wet mass. The evisceratedbody water content (EBWC) and the digestive gland water content (DGWC) are expressed as percentage.

The following indices were calculated: reproductive-somatic index $(\mathrm{RSI}=\mathrm{RM} \times 100 / \mathrm{EBM})$; digestive gland index $(\mathrm{DGI}=$ DGM x 100/EBM); visceral index (VI = VM x 100/EBM). Statistical comparisons between maturity stages of every sex were made for each variable using $t$ tests.

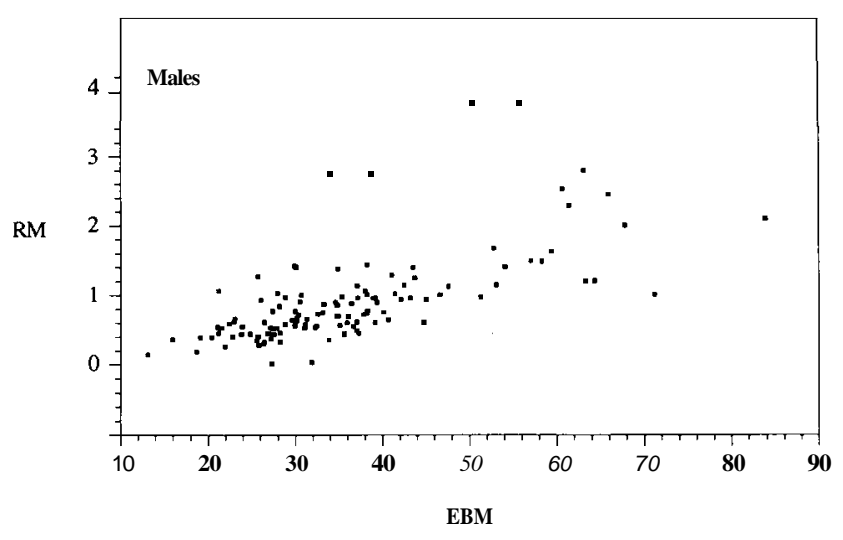

\section{Results}

Table I shows the values of BM, VI,EBWC ,DGI ,DGWC and RSI for each sex and maturity stage. The EBM/RM relationships for L. gahi males (A) and females (B) are illustrated in Fig. 1. The mass of reproductive organs increased progressively with growth in males, while in females these organs did not show a conspicuous increase in mass until a certain body mass was reached. At similar eviscerated body mass, males attained higher reproductive organ mass than females.

RSI ranged between 0.9 and 5.4 in males and 0.3 and 3.2 in females. Reproductive organ mass increased with maturity in both sexes (Table I). Males mature at a smaller size than females. The smallest mature male measured $96 \mathrm{~mm} \mathrm{ML}$, while the smallest mature female was $128 \mathrm{~mm}$ ML.

Water content in the eviscerated body mass ranged between $79.2-80.8 \%$ in males and $79.3-81.3 \%$ in females (Table I). Water content of the EBM in immature/maturing males was significantly higher than in mature males $(p<0.001)$. No significantdifferenceswere found among females. DGI ranged between $2.7-3.3$ in males and 3.2-3.7 in females (Table I).

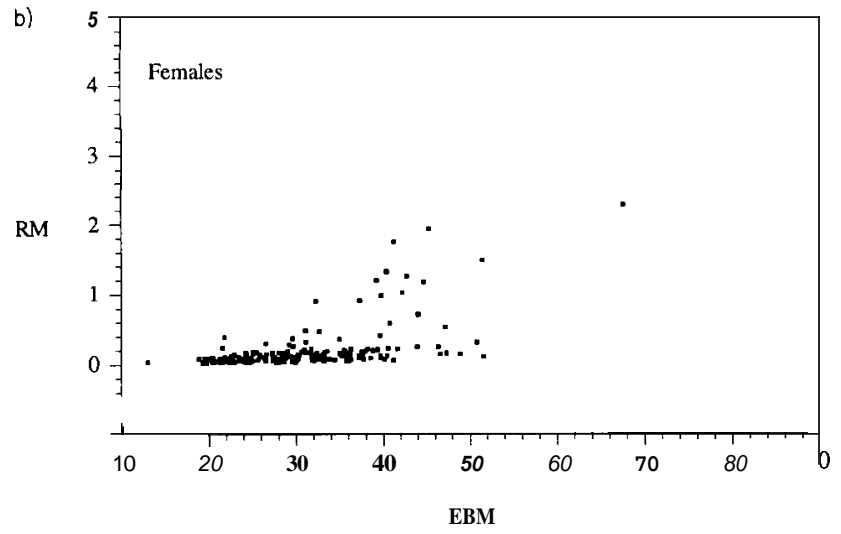

Fig.1 Eviscerate Body Mass (EBM); Reproductive Organs Mass (RM) relationships for Loligo gahi males (a) and females(b). 


\section{Discussion}

The number of mature females in the sample was very low, probably because the sample was taken in March when mature females are scarcein the fishery (Hatfield et al. 1991). During maturation here appears to be no shift from production in somatic tissues to reproductive organs. The squid's food apparently provides enough nutrients and energy forsexual development as observed in Illex argentinus (Hatfield et al. 1992, Rodhouse \& Hatfield 1992). L. gahi captured at the time of the present study showed evidence of active feeding (Guerra et al. 1991).

Moreover, water content in $L$. gahi did not increase with maturation. Increase of water content in cephalopod somatic tissue usually indicates its utilization, as in Sepia officinalis during starvation (Castro et al. 1992).

A major decrease in digestive gland size during starvation has been shown in Sepiaofficinalis (Castro etal. 1992). This would be expected if this gland were used for storage and subsequent mobilization of material for reproductive production. The digestive gland shows no mass loss during maturation in L. gahi; the ratio of digestive gland mass to eviscerated body mass did not change significantly during maturation (Table I). Likewise, no rise in the water content of the digestive gland was observed.

The present data suggest that growth of reproductive organs in L. gahi takes place using energy and nutrients derived from the squid's food and not by mobilizing nutrients and energy from somatic tissue. L. gahi spawns in shallow water and migrates down the continental shelf and slope after hatching. It then returns to shallow waters to spawn (Hatfield et al. 1990). Further data are required on the feeding behaviour of this species at different stages of its life cycle, but $L$. gahi probably feeds during the migration, so having no need to utilize somatic reserves for gamete production.

Similarly, Illex argentinus feeds, grows and starts to mature on the feeding grounds. When the squid migrates to the spawning ground, they may continue feed during the journey having no need to shift somatic tissue to reproductive material (Rodhouse \& Hatfield 1990, Hatfield et al. 1992, Rodhouse \& Hatfield 1992). The loliginid squid Alloteuthis subulata seems to show a similar pattern (Rodhouse et al. 1988). In Loligo opalescens and $L$. vulgaris reynaudii feedingbyfemalescontinues on the spawning grounds (Karpov \& Caillet 1978, Sauer \& Lipinski 1991).

Conversely, Illex illecebrosus matures during their $2000 \mathrm{~km}$ migration from the feeding to the spawning ground (O'Dor 1983). During this long trip the squid must pay the energetic cost for both maturation and locomotion (O'Dor \& Wells 1987). Fuel to cover both costs could be obtained from their own somatic tissue or from cannibalism (O'Dor \& Wells 1987). These patterns of reproductive/somatic relationships in cephalopods are probably closely related to the degree of semelparity/iteroparity of the species. Further research is necessary to determine how different reproductive patterns affect the investment of energy and nutrients in cephalopod somatic and reproductive tissues.

\section{Acknowledgements}

We express our gratitude to María Teresa Fernández for technical assistance and K.M. Mangold, M. Rasero, A. F. González, F. Rocha, T. Cortez and an anonymous referee for constructive criticism.

\section{References}

ANONYmous, 1989. Fisheries Report '87/88. Falkland Islands Interim Conservation and Management Zone. Stanley: Falkland Islands Government, 45 pp.

ARANCibla, H. \& Robotham, H.V. 1984. Crecimiento y edad en el calamar (Loligo gahi Orbigny) de la Región Austral de Chile.Investigación Pesquera (Chile) 31, 71-79.

BRAKONIECKI, T.F. 1986. A generic revision of the family Loliginidae (Cephalopoda; Myopsida) based primarily on comparative morphology of the hectocotylus. Ph.D. thesis, University of Miami, Florida, $163 \mathrm{pp}$. [Unpublished].

Castro, B.G., Garrido, J.L. \& Sotelo, C.G. 1992. Changes in composition of digestive gland and mantle muscle of the cuttlefish Sepia officinalis during starvation. Marine Biology, 114, 11-20.

Guerra, A, Castro, B.G. \& Nixon, M. 1991. Preliminary study on the feeding by Loligo gahi (Cephalopoda: Loliginidae). Bulletin of Marine Science, 49, 309-311.

HaMABE, M. 1969. Exhaution process of the genital organs of common squid, Ommastrephes sloani pacificus. Bulletin of the Japanese Sea Regional Fishery Research Laboratory, 111, 53-63.

HatmeLD, E.M.C. 1991. Post-recruit growth of the Patagonian squidLoligo gahi (d'Orbigny). Bulletin of Marine Science, 49, 349-361.

Hatfield, E.M.C., Rodhouse, P.G. \& Porebski, J. 1990. Demography and distribution of the Patagonian squid (Loligo gahi d'Orbigny) during the austral winter. Journal du Conseil International pour l'Exploration Scientifique de la Mer, 46, 306-312.

Hatfield, E.M.C., Rodhouse, P.G. \& Trathan, P.N. 1991. Recruitment of seasonal broods of the Patagonian squid (Loligo gahi, d'Orbigny) into the commercial fishery around the Falkland Islands: 1985 to 1990 . International Council for the Exploration of the Sea. ICES CM/K: 48, 17pp.

Hatfield, E.M.C., Rodhouse, P.G. \& Barber, D.L. 1992. Production of soma and gonad in maturing female Illex argentinus (Mollusca: Cephalopoda). Journal of the Marine Biological Association of United Kingdom, 72, 281-291.

Mangol.D, K.M., Young, R.E. \& NiXon, M. 1993. Growth versus maturation in cephalopods. In OKUTANI, T., O'Dor, R.K \& Kubodera, T. eds. Recent Advances in Cephalopod Fisheries Biology. Tokyo: Tokai University Press, 697-703.

Noolie, M.A.K. 1987. Fishery biology of the squid Loligo forbesi Steenstrup (Cephalopoda: Loliginidae) in Scottish waters. Ph.D. thesis, University of Aberdeen, 218 pp. [Unpublished.]

O'Dor, R.K. 1983. Illex illecebrosus. In BoY., P.R. ed. Cephalopod life cycles, vol. 1. London: Academic Press, 175-199.

O'DOR, R.K. \& WeLLS, M.J. 1978. Reproduction versus somatic growth: hormonal control in Octopus vulgaris. Journal of Experimental Biology, 77, 15-31.

O'Dor, R.K. \& WeLs, M.J. 1987. Energy and nutrient flow. In BoYu, P.R.ed. Cephalopod life cycles, vol 2. London: Academic Press, 109-133.

PATterson, K.R. 1988. Life history of Patagonia squid Loligo gahi and growth parameter estimates using least-squares fits to linear and von Bertalanffy models. Marine Ecology Progress Series, 47, 65-74.

RodHouse, P.G., SWINFEN, R.C. \& MURRAY,A.W.A. 1988. Life cycle, demography and reproductive investment in the myopsid squid Alloteuthis subulata. Marine Ecology Progress Series, 45, 245- 253.

Rodhouse, P.G. \& HATFIELD, E.M.C. 1990. Dynamics of growth maturation in the cephalopod Illex argentinus de Castellanos 1960 (Teuthoidea: 
Ommastrephidae). Philosophical Transactions of the Royal Society of London, B 329, 229-241.

Rodhouse, P.G. \& HatrielD, E.M.C. 1992. Production of soma and gonad in maturing male Illex argentinus (Mollusca: Cephalopoda). Journal of the Marine Biological Association of United Kingdom, 72, 293-300.

ROWE, L.V.\& MANGOLD, K. 1975. The effect of starvation on sexual maturation in Illex illecebrosus (Lesueur) (Cephalopoda: Teuthoidea). Journal of Experimental Marine Biology and Ecology, 17, 157-163.
SAUER, W.H.H. \& LIPINSKl, M.R. 1991. Food of the squid Loligo vulgaris reynaudii (Cephalopoda: Loliginidae) on their spawning ground off the eastern Cape, South Africa. South African Journal of Marine Biology, 10, 193-201.

TAIT, R.W. 1986. Aspects physiologiques de la senescence post reproductive chez Octopus vulgaris. Thèse de Doctorat d'Etat de l'Universitè de Paris VI, 250 pp. [Unpublished.] 